Revista de BIOLOGía TROPICAL

\title{
Life cycles of dominant mayflies (Ephemeroptera) on a torrent of the high Bolivian Andes
}

\author{
Carlos I. Molina ${ }^{1,3}$ \& Kenneth P. Puliafico ${ }^{2,3}$ \\ 1. Instituto de Ecología, Universidad Mayor de San Andrés, Casilla 10077, La Paz, Bolivia; camoar6088@gmail.com \\ 2. Institute of Pacific Islands Forestry, Pacific Southwest Research Station, USDA Forest Service, PO Box 236, Volcano, \\ HI, USA 96785; puliafico@gmail.com \\ 3. Natural History Museum of Denmark, University of Copenhagen, Universitetsparken 15, 2100 København Ø, \\ Denmark.
}

Received 17-XI-2014. Corrected 14-IX-2015. Accepted 16-X-2015.

\begin{abstract}
The mayflies of the temperate and cold zones have well-synchronized life cycles, distinct cohorts, short emergence and flight periods. In contrast, aquatic insects from the tropical zones are characterized by multivoltine life cycles, "non-discernible cohorts" and extended flight periods throughout the year. This report is the first observation of life cycle patterns made of two species of mayflies on a torrent in the high elevation Bolivian Andes. The samples were taken from four sites and four periods during a hydrological season. The life cycle of each species was examined using size-class frequency analysis and a monthly modal progression model (von Bertalanffy's model) to infer the life cycle synchrony type. These first observations showed a moderately synchronized univoltine life cycle for Andesiops peruvianus (Ulmer, 1920), whereas Meridialaris tintinnabula Pescador and Peters (1987), had an unsynchronized multivoltine life cycle. These results showed that the generalization of all aquatic insects as unsynchronized multivoltine species in the Andean region may not be entirely accurate since there is still a need to further clarify the life cycle patterns of the wide variety of aquatic insects living in this high elevation tropical environment. Rev. Biol. Trop. 64 (1): 275-287. Epub 2016 March 01.
\end{abstract}

Key words: Ephemeroptera, Meridialaris, Andesiops, life cycle, high Andes, Bolivia.

Neotropical mayflies are abundant in running waters in the mountain regions throughout the Andes Mountains of South America (Illies, 1969; Molineri, 2010). Aquatic insects, particularly of the order Ephemeroptera, are often used to help to assess water quality and are an indicator of environmental stress in continental hydrosystems (Statzner, Bis, Dolédec, \& Usseglio-Polatera, 2001), but in the Tropics their biology and ecology are still poorly known (Roldán, 2001; Ramírez \& GutiérrezFonseca, 2014). Knowledge of the life cycle pattern of the mayflies is important to set up conservation programs to preserve water quality and to gain a better understanding of the effects of climate change and its possible impacts on these sensitive high elevation sites.
Life cycles of freshwater macroinvertebrates have mainly been studied in the temperate Northern Hemisphere. In these areas, the alternation of warm and cold seasons is a fundamental determinant of insect life history and development patterns. The dominant model is the univoltine type characterized by the development of one generation per year. In 1970, Hynes wrote, "Animals with more than one generation a year are, as far as we know, relatively scarce in the running water habitat". Ephemeroptera are especially useful as biological indicators because the adults of most species are extremely short lived and the nymphs can be found in the water almost year round. Adult emergence and mating usually takes place en masse at a specific season of the 
year; therefore, every period of the nymphs' life cycle is then characterized by the presence of one dominant developmental stage. Development time can be modified locally by changes in water temperature (Ulfstrand, 1968; Mackay, 1979). In colder areas where growth is slower, semivoltine species require two or three years to complete a single generation. In contrast, some species in warmer areas have bivoltine or multivoltine life cycles, with two or more generations per year. In all these situations, there is a synchronization of the biological cycle in the time of adult emergence; as a result, there are one- (univoltine or semivoltine species), two- (bivoltine species), or more (multivoltine species) discrete periods of flight per year (Beam \& Wiggins, 1987; Giberson \& Rosenberg, 1992).

In the Neotropics, the few published reports available indicate that mayflies have more variable life cycle strategies. Subtropical cold water species showed a synchronized development time within species, but variability between species. For example, studies carried out in Patagonia mountain streams by Hollman and Miserendino (2006), showed one species as bivoltine (Meridialaris chiloeensis Demoulin, 1955 (Leptophlebiidae)) and another as univoltine (Metamonius anceps (Eaton, 1883) (Nesameletidae)). Epele, Miserendino and Pessacq (2011) obtained a similar result on two Baetidae: Andesiops peruvianus (Ulmer, 1920) and A. torrens (Lugo-Ortiz and McCafferty, 1999), both showing moderately synchronized univoltine life cycles but with different periods of peak nymphal development. In warmer tropical areas, multivoltine development patterns were observed, with asynchronous biological cycles due to abiotic conditions only partially related the seasons (e.g. wet-dry seasons). The first report documenting this development strategy came from Jackson and Sweeney (1995), where most of the Costa Rica mayflies were characterized by a multivoltine life cycle. In the same area, Vásquez, Wills-Flowers and Springer (2009) reported the same life cycle patterns for two Baetidae species.
The life cycle of larval development of the aquatic insects in the tropical high elevation Andean region has not been reported until now. The streams and rivers in the Andean region have unique climatic conditions driven by elevation, latitude and the influences of the moist air masses from the Amazon lowlands. First, there is not a clear pattern seasonality in temperature (e.g., from winter to summer), but a clear differentiation between wet and dry seasons. Secondly, high rainfall events match with high water temperatures, and when the rainfall decreases, it coincides with lower water temperatures but with higher temperature fluctuation (due to low temperature patterns and intense solar radiation). Our aim was to document the life cycle patterns and to analyze synchrony in growth patterns of two mayfly species on a torrent of the high Bolivian Andes. This report adds new data and builds on a previous study where the temporal-spatial abundances of several macroinvertebrates, including A. peruvianus and Meridialaris tintinnabula Pescador and Peters (1987), were documented from running water in the high Andes (Molina, Gibon, Pinto, $\&$ Rosales 2008). This paper provides the first evidence of mayfly life cycles from high elevation sites in the Bolivian Andes, and provides the basis for further exploration of this topic.

\section{MATERIALS AND METHODS}

The samples were taken in Bolivia, approximately $36 \mathrm{~km}$ Southeast of the city of La Paz, on the Rio Choquecota $\left(16^{\circ} 28^{\prime} 41.6^{\prime \prime}\right.$

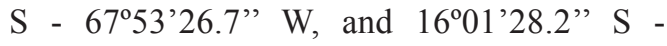
$\left.67^{\circ} 54^{\prime} 33.8^{\prime \prime} \mathrm{W}\right)$. It is a typical headwater stream from the Andean region (Cordillera Real, Amazon watershed). The glacier Mururata is the origin of the water system. The area is characterized by steep mountains, ranging from 3500 to $5800 \mathrm{~m}$, and high elevation tropical climate (Fig. 1). The presence of glaciers makes it possible for continual water flow throughout the year, while precipitation inputs are from rainfall mainly influenced by Amazonian warm air masses and winds from the Atlantic slope (Lorini, 1991). 


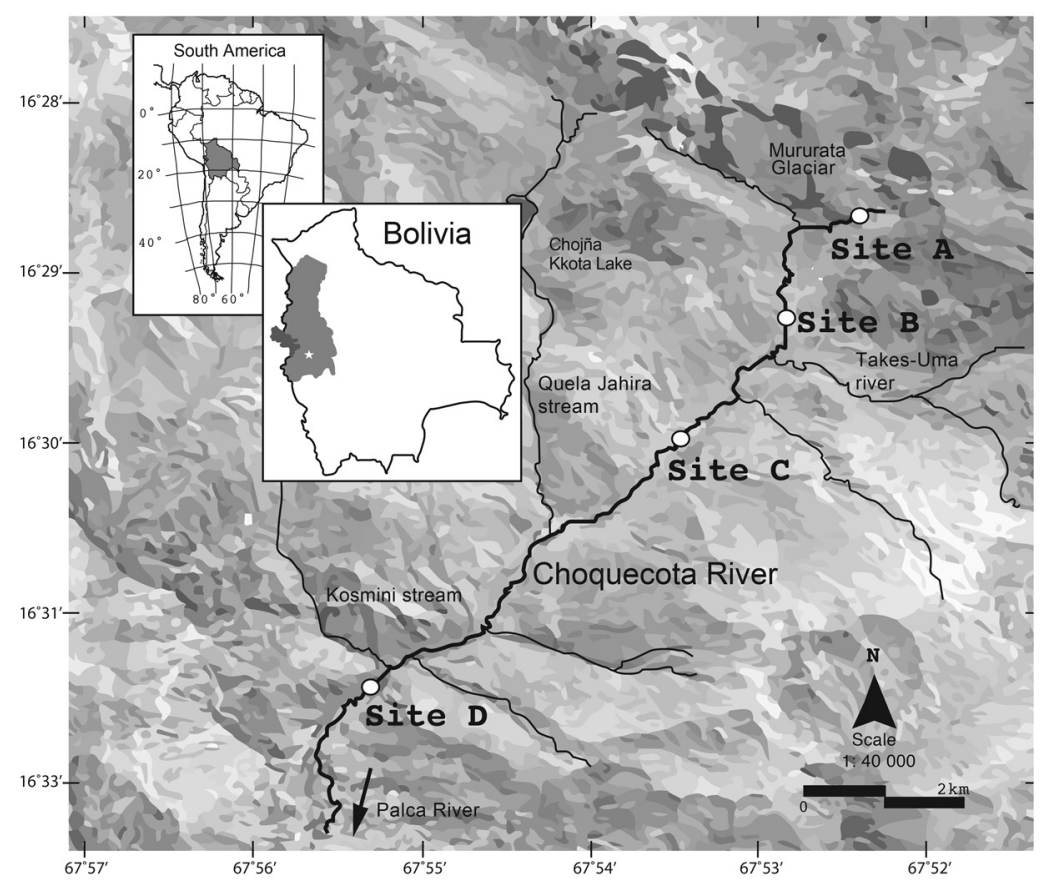

Fig. 1. Sampling sites in the Choquecota River.

The annual rainfall cycle is unimodal (Fig. 2). The duration of the wet season is usually short (December-March), with the highest intensity precipitation during the last two months (February and March), then rainfall decreases rapidly and the lowest precipitation is from June to July (dry season), after which the rainfall increases again (Lorini, 1991; Soruco et al., 2003). Molina et al. (2008) found that stream temperatures remain cold throughout the year (ranges from 4 to $13{ }^{\circ} \mathrm{C}$ ), and are warmer downstream $\left(2.5{ }^{\circ} \mathrm{C}\right.$ difference between 3600 and $4400 \mathrm{~m}$ ). The water temperatures follow the annual rainfall pattern; when the wet season starts the highest temperatures were recorded $\left(13 \pm 2{ }^{\circ} \mathrm{C}\right)$; however, during the rainfall peak events in February, the temperature starts to decrease $(9.5 \pm 1.6$ ${ }^{\circ} \mathrm{C}$, due to low solar radiation from persistent cloudiness). During the dry season the lowest temperatures were recorded but with a high range of daily fluctuation $\left(4 \pm 4{ }^{\circ} \mathrm{C}\right)$. After July the water temperature becomes more stable and temperature increases with increased rainfall (Fig. 2). Throughout the year the $\mathrm{pH}$ varied

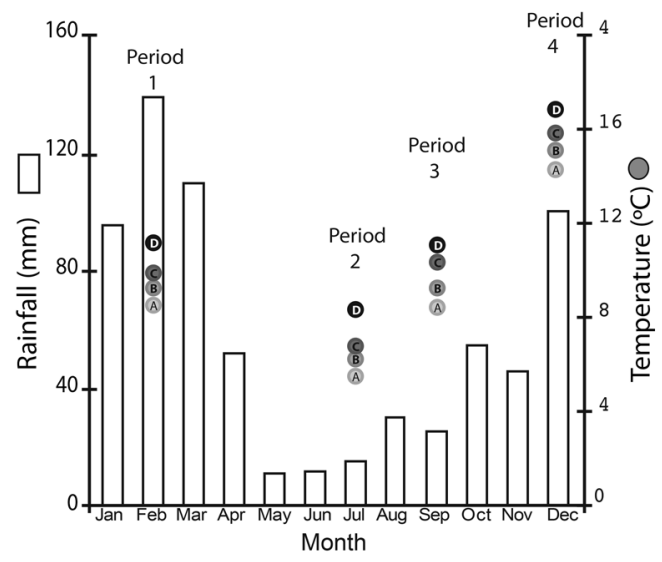

Fig. 2. Monthly average precipitation (meteorological station Huayna Potosi, Soruco et al. 2003), and water temperature registered from each site (circled letters) and time period sampled.

from 6.3 to 7.8 ; the dissolved oxygen from 5.52 to $8.33 \mathrm{mg} / \mathrm{L}$; the alkalinity from 6.1 to $52 \mathrm{mg} / \mathrm{L}$ (as $\mathrm{HCO}_{3}^{-}$); the sulphates from 15 to $46 \mathrm{mg} / \mathrm{L}$ (Molina et al., 2008). Stream vegetation is scarce, and the substrates are composed mainly of gravel and cobbles. There are no fish 
in the stream, though introduced trout occur in nearby ponds (Molina et al., 2008).

Four sampling trips were organized in 2002; the dates were chosen according to the hydrological seasons, one (February) during the wet season, one during the dry season (July), and two during the rising water season (September and December). Four study sites were sampled in each sampling period. The first collection site (Site A, elev. $4400 \mathrm{~m}$, discharge $0.0068 \pm 0.0056 \mathrm{~m}^{3} / \mathrm{s}$ ) is a first order stream running through the creeping vegetation (Distichia muscoisdes, Oxychloe andina) less than $500 \mathrm{~m}$ downstream of the glacier Mururata. Site B (elev. 4217 m, second order stream, discharge $\left.0.973 \pm 0.055 \mathrm{~m}^{3} / \mathrm{s}\right)$ and Site $\mathrm{C}$ (elev. $4000 \mathrm{~m}$, third order stream, discharge $\left.1.66 \pm 0.52 \mathrm{~m}^{3} / \mathrm{s}\right)$ are close to each other in open grassland of small-sized Poaceae (Festuca cf. andicola, Calamagrostis spp., and Stipa spp.). Finally, Site D (elev. $3613 \mathrm{~m}$, fourth order stream, discharge $5.077 \pm 2.963 \mathrm{~m}^{3} / \mathrm{s}$ ) is located below the village of Choquecota. The vegetation of the low elevation site (site $\mathrm{D}$ ) is a mosaic of bush (Baccharis incarum and $B$. boliviensis), crops (potato, bean) and exotic tree species (e.g. Eucalyptus globulus, Cupressus glabra).

The sampling was described in detail by Molina et al. (2008) and briefly summarized here. Larvae were collected with the kick sampling method (Abel, 1989), in the central channel of the river, covering an area of $1.5 \mathrm{~m}^{2}$ (length: $5 \mathrm{~m}$, width: $0.3 \mathrm{~m}$, net mesh opening: $250 \mu \mathrm{m})$. Samples were preserved in ethanol (75\%) for later examination. Densities of each mayfly species were calculated from the total count of all larval instars per unit of area. In order to complete the assessment of adult emergence times, adult mayfly flight activity was observed from all sites during each sample period. Trapping of adults was usually ineffective; therefore, they were captured by hand with a sweep net after carefully examining the stream banks to determine relative abundance. Adult and nymph specimens are stored in the Unidad de Limnología at the Universidad Mayor de San-Andres, La Paz, Bolivia.
Ephemeroptera larvae and adults were identified using regional keys for Baetidae (Nieto, 2004; Dominguez, Molineri, Pescador, Hubbard, \& Nieto 2006) and Leptophlebiidae (Pescador \& Peters, 1987; Dominguez et al., 2006). For each mayfly species, the width of the head capsule on each nymph was measured, using a dissecting microscope with an ocular micrometer (at 40x magnification). This method is the most commonly used technique to determine the developmental stage of nymphs of mayfly species (Brittain, 1982; Vásquez et al., 2009) and head capsule width has been found to be the best measure to explain life history patterns in similar studies (Epele et al., 2011).

We analyzed the size-class frequency by sampling period and site sampled. The cumulative size frequencies for each species were used to determine the number of size classes according to Sturges rule for determining the optimum number of groups or bars on a histogram (Sturges, 1926). The total area of the histograms was standardized to the Kernel density distribution to distinguish the cohort patterns. Potential asymmetry of growth patterns within the cohort was determined by the Skewness index (SK), where positive SK indicates that the tail of the distribution is stretched above the mean, whereas negative SK indicates that the tail of the distribution is stretched below the mean (Quinn \& Keough, 2002). Temporal-spatial size class distribution was compared using One-way Anova and multiple comparisons by Tukey's HSD test $(P>0.05)$. Statistical analyses were performed using R statistical software (R Core Team, 2013).

When significant differences in temporal growth patterns were found, a monthly modal progression was made to determinate the model of life cycle synchrony for the species. This procedure followed the von Bertalanffy's model, which has been widely applied in fishery biology and extends to invertebrates for tropical and temperate regions (Adjei-Boateng $\&$ Wilson, 2013). The model is based on physiological concepts of development, and has been found to fit data from a wide range of 
species. The von Bertalanffy equation used in terms of length, is:

$$
l_{t}=L_{\infty}\left(1-e-K\left(t-t_{o}\right)\right.
$$

where $l_{t}$ is the optimum length $(\mathrm{mm})$ at age $t$ (time), $L_{\infty}$ is the asymptotic length (mm), $K$ is the growth coefficient (per day), $t$ is the age (day) and $t_{o}$ is the theoretical age of the animal at a length equal to zero. The theoretical age data about tropical mayflies was found from Jackson and Sweeney (1995), and the rest of parameters were obtained from previous studies of growth frequency. This analysis was done in FiSAT II software (FAO-ICLARM Stock Assessment Tools; Version 1.2.2) (Gayanilo, Sparre, \& Pauly 2005).

\section{RESULTS}

Based on morphology of adults and nymphs only two species of mayflies were identified in our study: A. peruvianus (Baetidae) and $M$. tintinnabula (Leptophlebiidae). Each species was found in all sites in every sampling period (Table 1.).

We captured and measured 11654 total individual mayfly nymphs, with the majority belonging to $A$. peruvianus (9 080 nymphs) and the remaining corresponding to $M$. tintinnabula (2574 nymphs). The head capsule widths of these species had different but overlapping size ranges; A. peruvianus tended to be smaller size (ranges: 0.097 to $1.434 \mathrm{~mm}$ ), and M. tintinnabula included larger head capsule sizes (ranges: 0.100 to $2.152 \mathrm{~mm}$ ). Head capsule width of larvae for $A$. peruvianus were categorized into seven size classes (from a to $g$ ) with $0.191 \mathrm{~mm}$ intervals between classes, and in $0.186 \mathrm{~mm}$ intervals for M. tintinnabula with eleven size classes (from a to k) (Fig. 3 and Fig. 4). The head capsule sizes were proportional to body length for both species; with $A$. peruvianus reaching the average total length of 7.170 $\mathrm{mm}$ and the total average length of $M$. tintinnabula was $12.912 \mathrm{~mm}$ long in the final instar.

Temporal growth pattern for A. peruvianus showed an increase of size ranges from the first to the fourth sampling period (Fig. 3). The smallest size classes (primarily classes b and c) were collected in February $(0.474 \pm 0.206 \mathrm{~mm}$, $\mathrm{n}=1143$ larvae), moderate sized nymphs in the July and September $(0.551 \pm 0.215 \mathrm{~mm}, \mathrm{n}$ $=4366$ larvae and $0.560 \pm 0.213 \mathrm{~mm}, \mathrm{n}=2127$ larvae, sample periods 2 and 3 respectively), and the largest nymph sizes (predominately from classes c to $\mathrm{f}$ ) were found in December ( $0.659 \pm 0.228 \mathrm{~mm}, \mathrm{n}=1444$ larvae) (Fig. 3). The sizes were significantly different seasonally $\left(\mathrm{F}=164, \mathrm{P}<2 \mathrm{e}^{-16}\right.$, one-way Anova); however, there were no differences between for the second and third sampling periods $(\mathrm{P}=0.420$, Tukey's test). The growth pattern of the cohort tended to be more asymmetric in the first sampling period $(\mathrm{SW}=1.625)$, second $(\mathrm{SW}$ $=1.009)$ and third sampling periods ( $\mathrm{SW}=$ 0.910 ); whereas increased symmetry was found in the fourth sampling period ( $\mathrm{SW}=0.046$ ). Larvae with dark wing pads and high levels of

TABLE 1

Larvae density (individuals $/ \mathrm{m}^{2}$ ) of Ephemeroptera species collected from the center channel of the stream using standardized kick samples for each sampling period and site

\begin{tabular}{|c|c|c|c|c|c|c|c|c|c|c|c|c|c|c|c|c|}
\hline \multirow{2}{*}{ Family / Species } & \multicolumn{4}{|c|}{ February } & \multicolumn{4}{|c|}{ July } & \multicolumn{4}{|c|}{ September } & \multicolumn{4}{|c|}{ December } \\
\hline & A & $\mathrm{B}$ & $\mathrm{C}$ & $\mathrm{D}$ & A & B & $\mathrm{C}$ & $\mathrm{D}$ & A & B & $\mathrm{C}$ & $\mathrm{D}$ & A & B & $\mathrm{C}$ & $\mathrm{D}$ \\
\hline \multicolumn{17}{|l|}{ Baetidae } \\
\hline A. peruvianus & 929 & 27 & 134 & 53 & 338 & 1220 & 1424 & 1384 & 95 & 628 & 1236 & 168 & 144 & 716 & 320 & 264 \\
\hline \multicolumn{17}{|l|}{ Leptophlebiidae } \\
\hline M. tintinnabula & 10 & 30 & 72 & 68 & 24 & 137 & 211 & 448 & 24 & 252 & 604 & 140 & 33 & 212 & 288 & 21 \\
\hline
\end{tabular}

Sites arranged from highest to lowest elevations. 

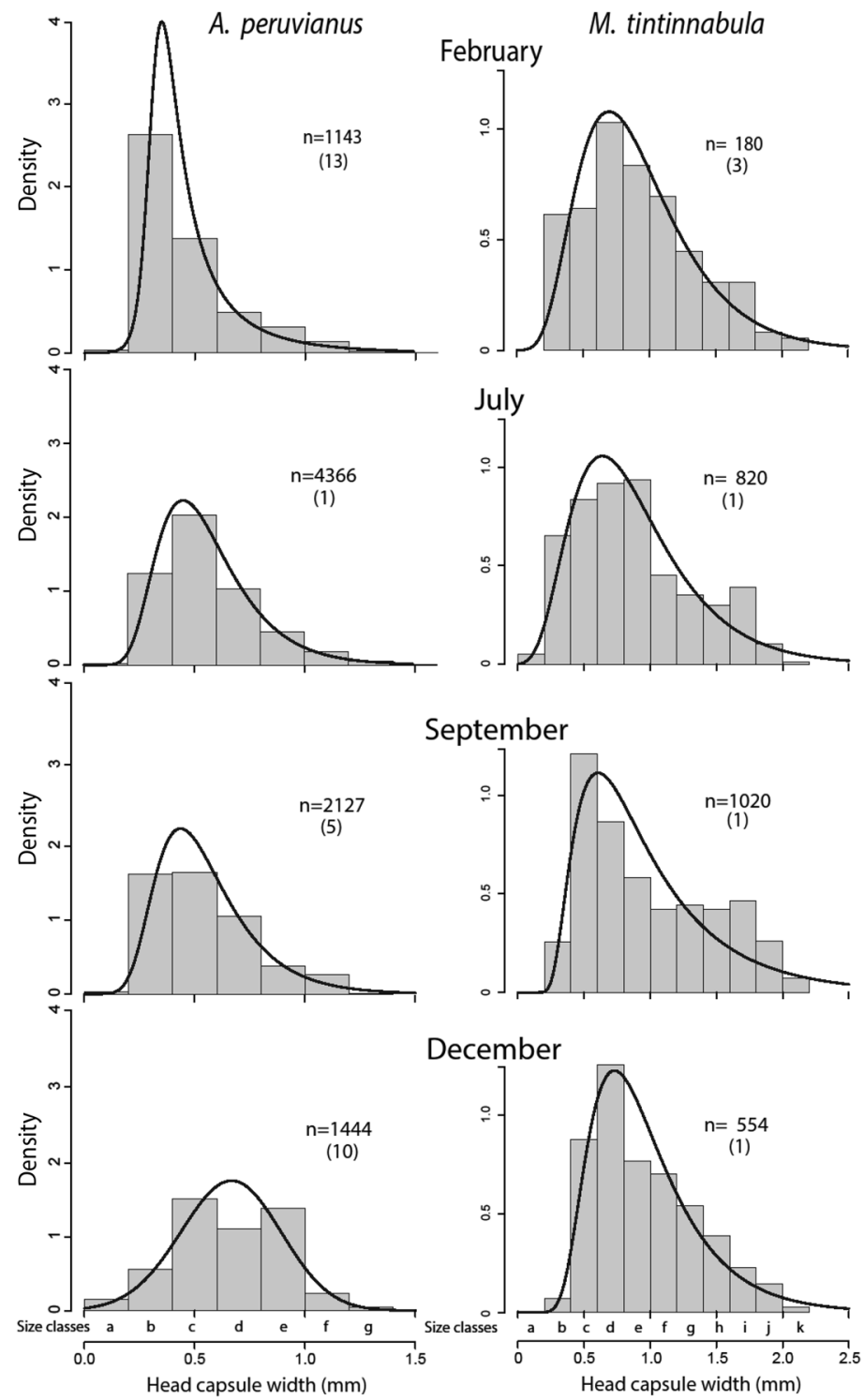

Fig. 3. A. peruvianus and M. tintinnabula larval density and frequency distribution of head capsule width across sampling periods. Total number of adults for each species captured during the sampling period shown in parentheses.

adult flight activity were recorded in the final December sample period (Fig. 3).

Because of the significant temporal differences in A. peruvianus, the von Bertallanfy growth function models were used to determine life cycle patterns. A single generation was detected in the models, as all models indicated that the estimated $t_{o}$ occurs only during the rainy season between November and mid-February (Fig. 5). The growth curves had similar slopes across sites $(K=1.038 \pm 0.353 /$ day $)$ and reached near asymptotic growth $\left(L_{\infty}\right)$ during the beginning of the wet season (Fig. 5). Variance in the models across sites indicated that larval development begins earlier in the rainy season at high elevation sites (Fig. 5A and Fig. 5B) 


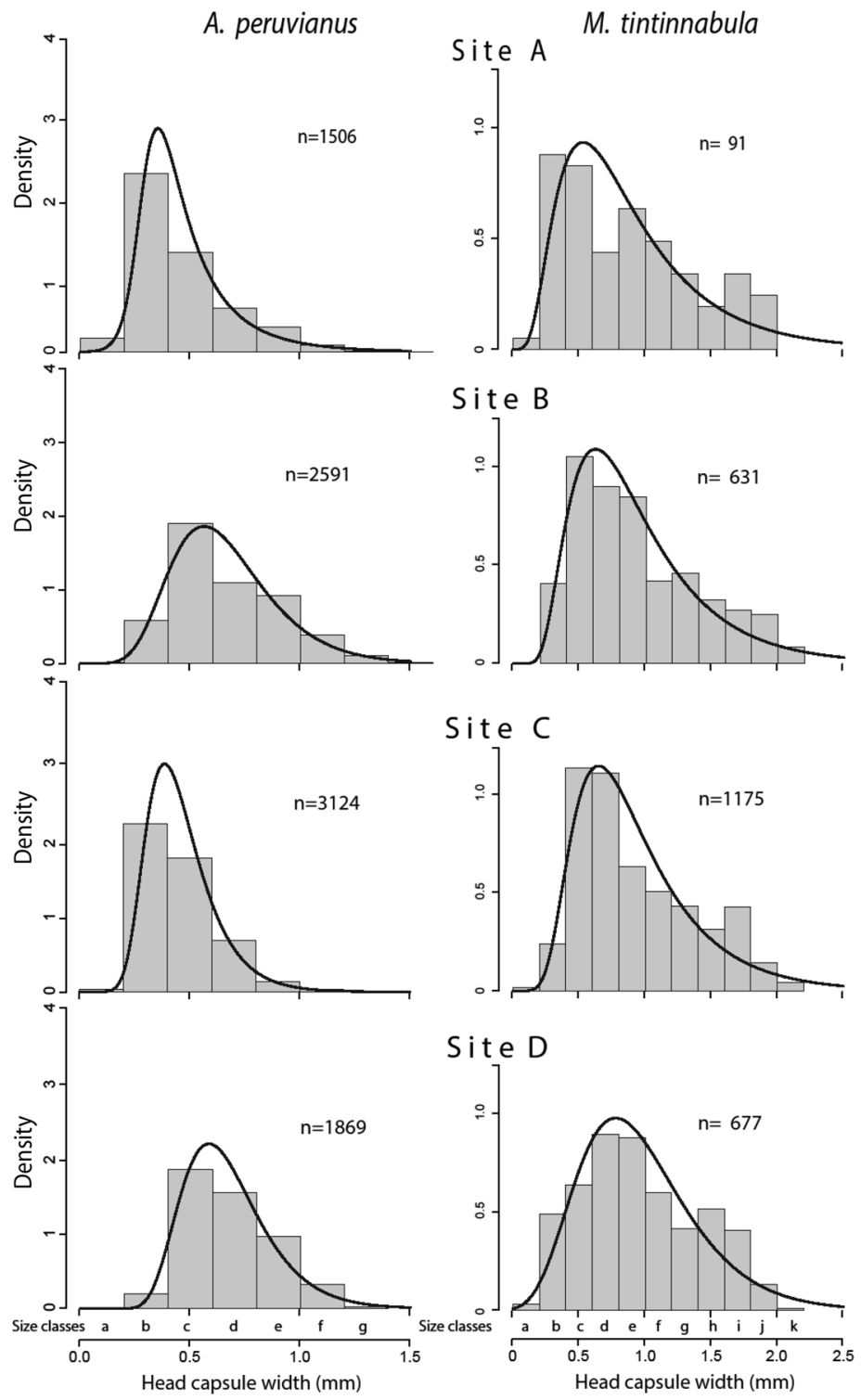

Fig. 4. A. peruvianus and M. tintinnabula larval density and frequency distribution of head capsule width across sampled sites (for all time periods combined).

compared to the lower elevation localities (Fig. $5 \mathrm{C}$ and Fig. 5D).

Temporal growth patterns for M. tintinnabula showed the same patterns of size class distribution in all of our sample periods. The head capsules of these nymphs tended to be grouped between 0.667 and $1.767 \mathrm{~mm}$ representing size classes c - f. Nymphs in July were significantly smaller compared with those collected in other time periods $(\mathrm{P}>0.05$ for period 2 versus all others, Tukey's test) (Fig. 3). Although statistically significant, the differences do not appear to be biologically important because it is less than one size class difference (average size of $0.961 \mathrm{~mm}$ for sample periods $1,3 \& 4$, versus $0.883 \mathrm{~mm}$ for sample period 2). In all sampling 


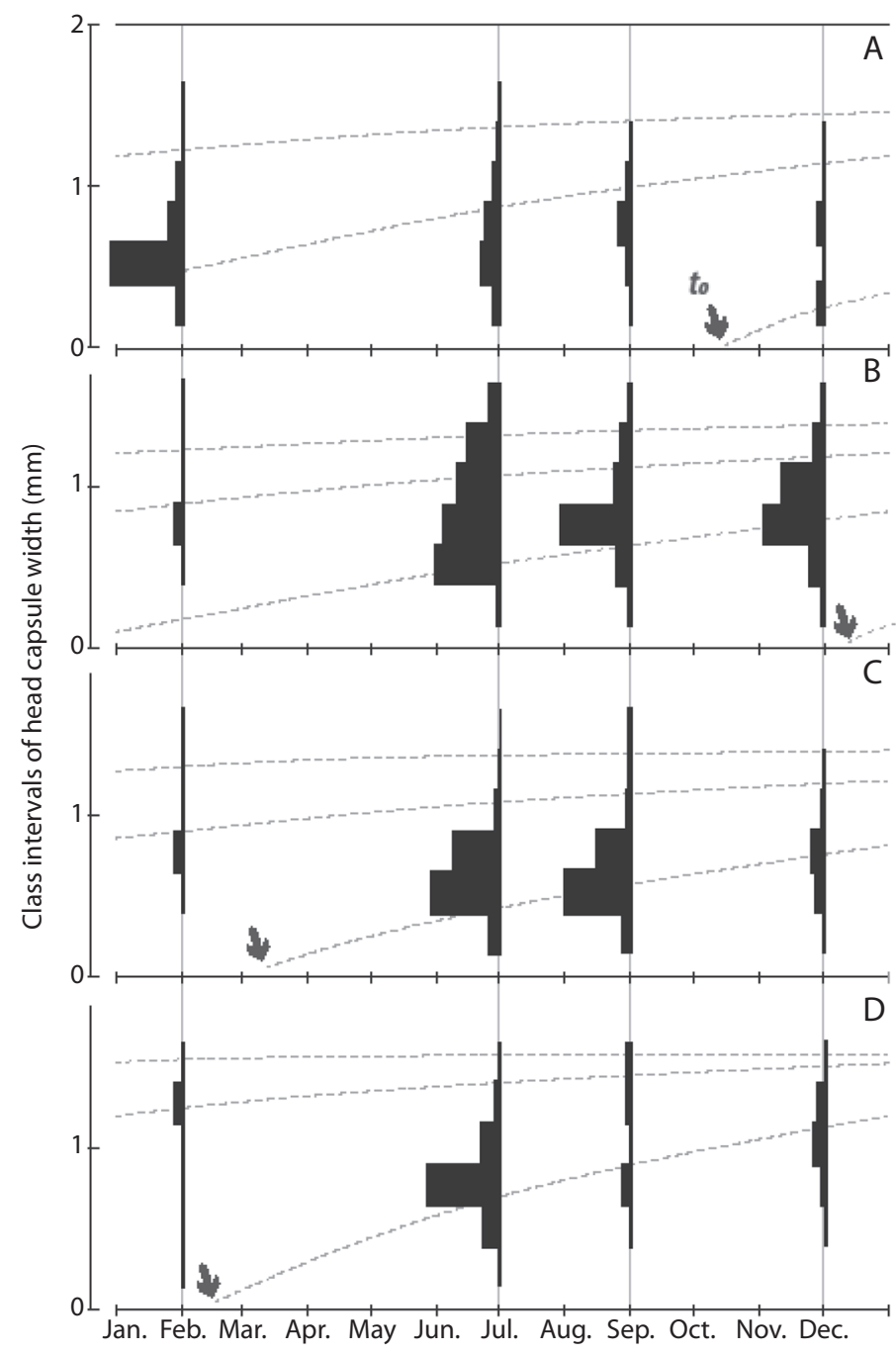

Fig. 5. A. peruvianus modal progression of the nymph head capsule width development observed at the sites (A - D) across sample periods. von Bertalanffy growth function shown with larval growth curve (dashed line), slope (growth coefficient K) and the upper limits bound by the maximum width $\left(\mathrm{L}_{\infty}\right.$, asymptote). The theoretical start of development times ( $\mathrm{t}_{\mathrm{o}}$, arrows) is roughly equivalent to the oviposition period. Note that the growth curves overlap from one year to the next as the end of development occurs at the same time as recruitment of the next cohort.

periods this mayfly typically showed an asymmetric cohort (average SK $=0.605$ ), where the population skewed toward the smaller sizes, with well over $50 \%$ of the larvae in smallest size classes (a to e); however, each of the larger size classes ( $\mathrm{h}-\mathrm{k}$ ) were consistently represented in these samples in small proportions. Adult in flight activities were observed along all periods and sites and without remarkable seasonal differences (Fig. 3).

Although there was a trend toward greater larval densities at lower elevations and later dates, the density and spatial distribution of the nymphs across the sites was not significantly different for either species because of the high degree of within site variation across sampling 
periods (Table 1). However, there were spatially explicit differences in growth patterns of A. peruvianus but not M. tintinnabula. A. peruvianus size classes appeared to be assembled in two groups that were significant different between each other $(\mathrm{P}<0.001$, Tukey's test) (Fig. 4). The first group of $A$. peruvianus was predominated by lower size classes at sites A (highest elevation) and C (0.464 $\pm 0.203 \mathrm{~mm}$, group average), while the other group had a higher proportion of larger size classes (sites $\mathrm{B}$ and $\mathrm{D}, 0.666 \pm 0.210 \mathrm{~mm}$, group average). In contrast, the size class distribution of $M$. tintinnabula between sites shared similar patterns of size class densities and there were no significant spatial differences detected (Fig. 4).

\section{DISCUSSION}

Considering mayflies' distribution, two species of mayflies were identified from our field sites in the high elevation Andes of Bolivia, A. peruvianus and M. tintinnabula; and Ephemeroptera comprised the largest component of the macroinvertebrate community at these sites, making up $85 \%$ of the all aquatic arthropods collected (Molina unpublished data, Molina et al. 2008). The density and distribution of these two species across sites indicates that $A$. peruvianus was the dominant species, accounting for $78 \%$ of the mayfly specimens collected. A. peruvianus was also recorded in Argentina, Colombia and Peru; however, the current study sites in Bolivia are at, or slightly above, the highest elevation reported in the literature for this species (1000 to $4300 \mathrm{~m}$ (Nieto, 2004)), and are considerably higher than previous life history studies (ca. $1200 \mathrm{~m}$ (Epele et al., 2011)). M. tintinnabula accounted for $22 \%$ of the mayfly specimens. Previous to this study, M. tintinnabula have only been recorded from the Andean region of Northwestern Argentina (Pescador \& Peters, 1987; Dominguez et al., 2006). The identification of M. tintinnabula was made from mature imagoes and represents the first record for the species in Bolivia.

In general, the lowest densities of macroinvertebrates were reported during the wet season
(February and December), and the highest when the flow decreased during the dry season (July and September) (Molina et al., 2008), and we found similar trends for M. tintinnabula. It is likely this is due to the stability of the water level and reduced turbulent flow from rain fed runoff. The densities the larger mayfly, M. tintinnabula, also tended to be lower at the highest elevation, low stream order site (Site A) and increased downstream in the higher order streams, but our data was too variable to detect statistical differences between sites. Larger streams may have more varied microhabitats and also provided greater allochthonous food imports which potentially support larger mayfly populations. The density of the smaller mayfly species $A$. peruvianus was higher but more variable across sample sites and dates and no strong trends in density and abundance were detected.

The observations and data models from this study suggest that $A$. peruvianus has a univoltine and moderately synchronized life cycle. We found significant differences in the size of larvae present throughout the hydrological season. The von Bertalanffy modal progression analysis of $A$. peruvianus indicates that a single generation of larvae occurs at each site across the sampling periods. The calculated values from the model for theoretical age $\left(t_{o}\right)$ coincided with the onset of the wet season from late October to December at the high elevation sites and later in February at the lower elevations. This factor can be interpreted as the time that larvae begin developing within the egg and is roughly equivalent to the oviposition period in the tropical environment. The model agrees with our February observation that a large proportion of the smallest larvae and only a few of the final instars nymphs are present; furthermore, these were accompanied by a large number of ovipositing adults on the stream banks. Therefore, we conclude that $A$. peruvianus eggs hatch in the wet season, and the nymphs start their development during the late wet (January - March) and wet-dry transition seasons (April-May). The intermediate nymph sizes occur during the dry season (July) 
and dry-wet transition season (September), and the larger size classes predominate during the wet season in December and January. Although a wide range of size classes were present during the intermediate growth stages we did not detect overlapping generations. Similarly, the modal progression models' growth coefficient (K) indicates the head capsule width experiences rapid growth rate early in the season and slows at the end of the larval development near the asymptote at the pre-imago stage during the wet season. Observations across sites in December show increases in higher size classes as well as increased cohort symmetry, as is expected at the completion of the final instars in the nymphs' life cycle. This life cycle pattern is similar to the pattern identified for this species in Patagonian streams by Epele et al. (2011), although, in our study the latitudinal ranges were different and elevations were higher.

The spatial variation in $A$. peruvianus size class distributions across sites formed two distinct groupings with nymphs from sites $\mathrm{A}$ and $\mathrm{C}$ significantly smaller than those from sites $\mathrm{B}$ and D. The modal progression models suggest that elevation has a significant impact on the beginning of larval development across these sites, but elevation alone does not explain the variation between these two groups. The difference in growth patterns we observed between sites is most likely driven by a combination of abiotic conditions including temperature, solar radiation and water chemistry. Molina et al. (2008) found there was a small correlation between Baetidae abundance on the Rio Choquecota and the level of dissolved oxygen, and $\mathrm{pH}$ of the water. Although they did not specifically investigate the effects of temperature on mayflies at these sites (Molina et al., 2008), other studies have shown that water temperature differences can also strongly influence the growth rate of Ephemeroptera (Brittian, 1982). Water temperature in the high Andes is especially variable due to the effects of high solar radiation in this mountainous environment. Solar radiation has a direct effect on the amplitude of heating daytime water temperatures (Wasson,
Guyot, Dejoux, \& Roche, 1989), but can indirectly cause cooling of afternoon and nighttime stream temperatures through the release of cold glacial melt water. A. peruvianus from sites $\mathrm{A}$ and $\mathrm{C}$ may be exposed to more solar radiation because the water channel is open (Molina et al., 2008), and therefore may face harsher environmental conditions than more sheltered sites. The high amount of solar radiation may also adversely affect diurnal foraging behavior of these mayfly nymphs. Furthermore, the open channels of sites $\mathrm{A}$ and $\mathrm{C}$ may also limit the availability of allochthonous food from overhanging vegetation which provides important nutritional supplements to the slow growing algae of these cold mountain streams.

Our results suggest an unsynchronized multivoltine life cycle for $M$. tintinnabula in these tropical mountainous sites. The temporalspatial growth pattern for M. tintinnabula, showed overlapping generations and the same life history patterns, with the full range of size classes present at every sampling period. Although the July observations were significantly smaller than the rest of the year, we assert that this was not of biological importance since the differences in sizes were minimal between sampling periods and the larvae were still concentrated within the overall predominate size classes ( $\mathrm{c}$ to f). Adult flight activities were observed along all sites and sampling periods, but without notable changes in abundance between sampling periods. The lack of size class pattern variation between sample sites for $M$. tintinnabula may indicate that this species has a wider tolerance for different abiotic water conditions. This finding was supported in the previous study by Molina et al. (2008), where was no correlation between Leptophlebiidae abundance and any of the six abiotic factors investigated at the same sites in an ordination analysis.

M. tintinnabula's unsynchronized multivoltine life cycle, and growth pattern from our study does not concur with other congeneric species studied in subtropical intermediate latitudes. M. diguillina Demoulin, 1955 was studied by Gonser and Spies (1997), and 
M. chiloeensis was studied by Hollmann and Miserendino (2006), and these authors have characterized their respective species as having bivoltine life cycles, but they also recognized the poor developmental synchronization and overlapping generations of nymphs. Of course, density and growth ranges can vary depending on hydrological conditions (including water temperature and stream flow), but in our study all the developmental stages coexist throughout the year, including active adults, which supports our conclusion of unsynchronized multivoltinism for this species in Bolivia.

In conclusion, the fact that these two species can have different life history strategies while sharing the same stream environment indicates that they adopted different developmental pathways to ensure their survival in this uniquely variable watershed. Observations of co-occurring species having either a univoltine life cycle of that is moderately synchronized (A. peruvianus) or an unsynchronized multivoltine life cycle ( $M$. tintinnabula), suggests that both strategies may give an advantage to these species, but possibly at different times. Evidence from closely related species and the highly variable nature of nymphal development in these high elevation populations suggests that both species may have started from a previously clearly synchronized and either univoltine or bivoltine models. M. tintinnabula showed a rapid adaptation to the prevailing environmental conditions in the high Andean mountains, because all the larval stages, as well as adult flight activities were recorded throughout the entire hydrological season. A. peruvianus still relies on its moderately synchronized development culminating during the warm-wet season to emerge from the water, mate and lay eggs together; however, the nymphs of this species also appeared to maintain a large degree of developmental flexibility. Indeed, both mayflies studied are populations that can change their life cycle in order to counteract the variability of environmental conditions found in this mountainous habitat.

Finally, the generalization that aquatic insects from the Andean region have unsynchronized multivoltine species has been shown to be ambiguous at best, and inaccurate in the case of these populations of A. peruvianus. Our study indicates that there is a need to clarify the definition of life cycles of many aquatic insects living in this particular environment to better understand their changes in abundance throughout the year. This information would better inform future studies on the sensitivity of these aquatic organisms to differences in water quality and climatic changes.

\section{ACKNOWLEDGMENTS}

Many thanks to François-Marie Gibon for his constant and unconditional support to research the aquatic insect from the Andean region. We are grateful to Claudio Rosales whose participation during missions and laboratory work was invaluable. Eduardo Dominguez provided useful comments on the first manuscript version. Particular thanks to the anonymous reviewer who gave important suggestions that greatly improved the manuscript.

\section{RESUMEN}

Ciclos de vida de las efímeras (Ephemeroptera) en un torrente de los Andes bolivianos de altura. Los efemerópteros en las zonas templadas y frías, tienen ciclos de vida bien sincronizados, cohortes claras, períodos cortos de emergencia y vuelo. Por el contrario, los insectos aquáticos de las zonas tropicales se caracterizan por ciclos de vida multivoltino, "cohortes no claras" y periodos extendidos de vuelo durante el año. Estas son las primeras observaciones de los patrones del ciclo de vida realizados en dos poblaciones de efemeropteros en un torrente de tierras altas en los Andes de Bolivia. Las muestras se tomaron en cuatro sitios y cuatro periodos durante una temporada hidrológica. El ciclo de vida fue analizado por frecuencia de clases de tallas, y por progresión modal mensual (modelo de von Bertalanffy), con el fin de inferir el tipo de sincronía del ciclo de vida. Estas primeras observaciones mostraron un ciclo de vida univoltino y moderadamente sincronizado para Andesiops peruvianus, mientras que para Meridialaris tintinnabula fue multivoltino desincronizado. Estos resultados muestran que la generalización de todos los insectos acuáticos como especies multivoltina y no sincronizadas en la región andina no puede ser completamente exacta, ya que todavía hay una necesidad de aclarar la definición de los patrones del ciclo de vida de muchos insectos acuáticos que viven en este ambiente tropical de elevada altura. 
Palabras clave: Ephemeroptera, Meridialaris, Andesiops, ciclo de vida, Andes de zonas altas, Bolivia.

\section{REFERENCES}

Abel, P. D. (1989). Water pollution biology. Chichester, England, UK: Ellis Horwood.

Adjei-Boateng, D., \& Wilson, G. J. (2013). Age determination and growth rate of the freshwater clam Galatea paradoxa (Born 1778) from the Volta River estuary, Ghana. African Journal of Aquatic Science, 1(2), 31-38.

Beam, B. D., \& Wiggins, G. B. (1987). A comparative study of the biology of five species of Neophylax (Trichoptera: Limnephilidae) in southern Ontario. Canadian Journal of Zoology, 65(7), 1741-1754.

Brittain, J. E. (1982). Biology of mayflies. Annual Review of Entomology, 27, 119-147.

Dominguez, E., Molineri, C., Pescador, M. L., Hubbard, M. D., \& Nieto, C. (2006). Ephemeroptera of South America: Aquatic biodiversity in Latin America (ABLA Vol. 2). Sofia-Moscow: Pensoft.

Epele, L. B., Miserendino, M. L., \& Pessacq, P. (2011). Life history, seasonal variation and production of Andesiops torrens (Lugo-Ortiz and McCafferty) and Andesiops peruvianus (Ulmer) (Ephemeroptera: Baetidae) in a headwater Patagonian stream. Limnologica, 41, 57-62.

Gayanilo, F. C., Sparre, P., \& Pauly, D. (2005). FAOICLARM Stock assessment tools II (FiSAT II): User's guides (Revised version). Rome: FAO Computerized Information Series (Fisheries).

Giberson, D. J., \& Rosenberg, D. M. (1992). Effects of temperature, food quantity, and nymphal rearing density on life-history traits of a northern population of Hexagenia (Ephemeroptera: Ephemeridae). Journal of the North American Benthological Society, 11, 181-193.

Gonser, T., \& Spies, M. (1997). Southern hemisphere Symbiocladius (Diptera, Chironomidae) and their mayfly hosts (Ephemeroptera, Leptophlebiidae). In P. Landolt, \& M. Sartori (Eds.). Ephemeroptera \& Plecoptera: Biology-Ecology-Systematics (pp. 455 466). Fribourg, Switzerland: MTL-Mauron+Tinguely \& Lachat SA.

Hollmann, M. E. T., \& Miserendino, M. L. (2006). Habitat preference and life history of the mayflies Metamonius anceps Eaton (Nesameletidae) and Meridialaris chiloeensis Demoulin (Leptophlebiidae) in a Patagonian mountain stream. Annales de Limnologie International Journal of Limnology, 42(4), 233-240.

Hynes, H. B. N. (1970). The ecology of running waters. Toronto, Canada: University of Toronto Press.
Illies, J. (1969). Biogeography and ecology of Neotropical freshwater insects, especially those from running waters. In E. J. Fittkau, J. Illies, H. Klinge, G. H. Schwabe, \& H. Sioli (Eds). Biogeography and ecology in South America (pp. 685-708). The Hague: Dr. W. Junk N. V., Publishers.

Jackson, J. K., \& Sweeney, B.W. (1995). Egg and larval development times for 35 species of tropical stream insects from Costa Rica. Journal of the North American Benthological Society, 14(1), 115-130.

Lorini, J. (1991). Clima. In E. Forno \& M. Baudoin (Eds). Historia natural de un valle de los Andes: La Paz (p. 36). La Paz, Bolivia: Instituto de Ecología - UMSA.

Mackay, R. J. (1979). Life history patterns of some species of Hydropsyche (Trichoptera: Hydropsychidae) in southern Ontario. Canadian Journal of Zoology, 57, 963-975.

Molina, C. I., Gibon F. M., Pinto, J., \& Rosales, C. (2008). Estructura de macroinvertebrados acuáticos en un río altoandino de la Cordillera Real, Bolivia: variación anual y longitudinal en relación a factores ambientales. Ecología Aplicada, 7(1,2), 105-116.

Molineri, C. (2010). The influence of floods on the life history of dominant mayflies (Ephemeroptera) in a subtropical mountain stream. Studies on Neotropical Fauna and Environment, 45(3), 149-157.

Nieto, C. (2004). South American Baetidae (Ephemeroptera): a new generic synonymy. Studies on Neotropical Fauna and Environment, 39(2), 95-101.

Pescador, M. L., \& Peters, W. L. (1987). Revision of the genera Meridialaris and Massartellopsis (Ephemeroptera: Leptophlebiidae: Atalophlebiinae) from South America. Transactions of the American Entomological Society, 112, 147-189.

Quinn, G. P., \& Keough, M. J. (2002). Experimental design and data analysis for biologists. New York, NY: Cambridge University Press.

R Core Team (2013). R: A language and environment for statistical computing (Version 3.1.2) c[Software]. Vienna, Austria: R Foundation for Statistical Computing. Retrieved from http://www.R-project.org/

Ramírez, A., \& Gutiérrez-Fonseca, P. E. (2014). Estudios sobre macroinvertebrados acuáticos en América Latina: avances recientes y direcciones futuras. Revista de Biología Tropical, 62(2), 9-20.

Roldán, G. (2001). Los macroinvertebrados de agua dulce de los Andes tropicales. In R. Primack, R. Rozz, P. Feinsinger, R. Dorzo, \& F. D. F. Nassardo (Eds.), Fundamentos de concervacion, biología y perpectivas latinoamericanas (pp. 122-125). Mexico: Fondo de Cultura Económica.

Soruco, A., Rabatel, A., Chazarin, J. P., Gallaire, R., Fuertes, R., Ribstein, P., Wagnon, P., \& Valdivieso, 
H. (2003). Medidas metereológicas, hidrológicas y glaciológicas sobre el glacial Zongo (pp. 18). La Paz, Bolivia: Institut de Recherche pour Développement - IRD.

Statzner, B., Bis, B., Dolédec, S., \& Usseglio-Polatera, P. (2001). Perspectives for biomonitoring at large spatial scales: a unified measure for the functional composition of invertebrate communities in European running waters. Basic and Applied Ecology, 2, 73-85.

Sturges, H. A. (1926). The choice of a class interval. Journal of the American Statistical Association, 21, 65-66.
Ulfstrand, S., (1968). Life cycles of benthic insects in Lapland streams (Ephemeroptera, Plecoptera, Trichoptera, Diptera: Simuliidae). Oikos, 19, 167-190.

Vásquez, D., Wills-Flowers, R., \& Springer, M. (2009). Life history of five small minnow mayflies (Ephemeroptera: Baetidae) in a small tropical stream on the Caribbean slope of Costa Rica. Aquatic Insects, 31, 319-332.

Wasson, J. G., Guyot, J. L., Dejoux, C., \& Roche, M. A. (1989). Régimen térmico de los ríos de Bolivia. La Paz, Bolivia: O.R.S.T.R.O.M. Convenio Hidrobiología - Programa PHICAB U.M.S.A. 
